\title{
Fine mapping of a recessive leaf rust resistance locus on chromosome 2BS in wheat accession $\mathrm{CH} 1539$
}

\section{Dece Sheng ( $\nabla$ dece.sheng@qq.com )}

Shanxi University https://orcid.org/0000-0001-9249-5044

\section{Linyi Qiao}

Shanxi Agricultural University

\section{Xiaojun Zhang}

Shanxi Agricultural University

Xin Li

Shanxi Agricultural University

\section{Lifang Chang}

Shanxi Agricultural University

Huijuan Guo

Shanxi Agricultural University

\section{Shuwei Zhang}

Shanxi Agricultural University

\section{Fang Chen}

Shanxi Agricultural University

\section{Zhijian Chang}

Shanxi Agricultural University

\section{Research Article}

Keywords: Wheat, Leaf rust, Seedling resistance, Fine-mapping

Posted Date: February 7th, 2022

DOI: https://doi.org/10.21203/rs.3.rs-1298140/v1

License: (1) (i) This work is licensed under a Creative Commons Attribution 4.0 International License. Read Full License 


\section{Abstract}

Leaf rust, caused by Puccinia triticina $(P t)$, is one of the most important fungal diseases of wheat worldwide. The wheat accession $\mathrm{CH} 1539$ showed a high level of resistance to leaf rust. A mapping population of 184 recombinant inbred lines (RILs) was developed from a cross between the resistant accession $\mathrm{CH} 1539$ and the susceptible cultivar SY95-71. The RILs showed segregating infection responses to Puccinia triticina Eriks. (Pt) race THK at the seedling stage. Genetic analysis showed that leaf rust resistance was controlled by a monogenic gene, and the potential locus was temporarily named $\mathrm{LrCH} 1539$. Bulked segregant analysis (BSA) using a 35K DArTseq array located $\mathrm{LrCH} 1539$ on the short arm of chromosome 2B. Subsequently, a genetic linkage map of $\mathrm{LrCH} 1539$ was constructed using the developed 2BS chromosome-specific markers, and its flanking markers were sxau-2BS136 and sxau-2BS81. An $\mathrm{F}_{2}$ subpopulation with 3619 lines was constructed by crossing the resistant and susceptible lines selected from the RIL population. The inoculation identification results showed that $\mathrm{LrCH} 1539$ was recessively inherited and was fine-mapped to a 779.4-kb region between markers sxau-2BS47 and sxau-2BS255 at the end of 2BS. The linkage marker analysis showed that the positions of $L r C H 1539$ and $L r 16$ were the same, but the identification results of the resistance spectrum indicated that the causal genes of the two might be different. The resistant materials reported in this study and the cosegregation marker can be used for marker-assisted selection breeding of leaf rust-resistant wheat cultivars.

\section{Introduction}

Leaf rust, caused by Puccinia triticina Eriks. (Pt), is a worldwide disease of wheat (Huerta-Espino et al. 2011; Kolmer 2005). It occurs more frequently than other rusts and is more common worldwide (Ellis et al. 2014). In recent years, leaf rust has become an increasingly significant disease in the major wheat production regions of China (Li et al. 2014; Zhang et al. 2020), and more than 15 million hectares of wheat are affected by leaf rust annually (Gao et al. 2019). The use of disease-resistant cultivars is the most efficient and environmentally friendly way to prevent yield losses from this disease worldwide (Pink 2002).

To date, 80 permanently named and numerous temporarily designated leaf rust resistance genes ( $L r$ genes) and quantitative trait loci (QTLs) have been reported in wheat (Kumar et al. 2021). Although the number of designated $L r$ genes is increasing annually, new LR races with new virulence(s) that can overcome some of these $L r$ genes will likely occur (Ren et al. 2015). Lrgenes such as Lr1, Lr3, Lr3bg, Lr10, Lr11, Lr14a, Lr16, and Lr26, which are common in Chinese wheat cultivars, have been nearly ineffective when applied alone (Gao et al. 2019; Li et al. 2010; Zhao et al. 2013). Therefore, to ensure the genetic resistance of wheat, it is essential to identify new or effective resistance genes in different germplasms of wheat varieties or related species worldwide.

Meanwhile, fully use the discovered resistance resources and improve the efficiency of breeding selection, it is necessary to develop more effective selection markers for resistance genes, which will also lay the foundation for cloning genes and studying their resistance mechanisms. Currently, only few race-specific seedling resistance genes (including $L r 1, L r 10, L r 14 a$, and $L r 21$ ) and few adult plant resistance genes (including $L r 22 a, L r 34$, and $L r 67$ ) have been cloned (Cloutier et al. 2007; Feuillet et al. 2003; Huang et al. 2003; Kolodziej et al. 2021; Krattinger et al. 2009; Moore et al. 2015; Thind et al. 2017). The remaining large number of leaf rust resistance genes/QTLs have not been finely mapped and cannot be efficiently used in marker-assisted selection (MAS).

The wheat accession $\mathrm{CH} 1539$ developed by our laboratory has shown a high level of resistance to leaf rust in the field environment for many years. In this study, genetic analysis was performed on the resistance of the RIL 
constructed by $\mathrm{CH} 1539$ and a susceptible parent using the race THK. BSA combined with a wheat DArTseq array was used to determine the gene locus of resistance to leaf rust; a subpopulation was constructed to fine map this gene, and a cosegregation marker was developed to better use the germplasm.

\section{Materials And Methods}

\section{Plant materials and Pt races}

An RIL mapping population containing $184 \mathrm{~F}_{2: 10}$ lines was developed from the cross between the resistant accession $\mathrm{CH} 1539$ and the susceptible cultivar SY95-71. The accession $\mathrm{CH} 1539$ developed by the College of Agriculture, Shanxi Agricultural University (Shanxi Key Laboratory of Crop Genetics and Molecular Improvement) has a high level of resistance to leaf rust, and the wheat cultivar SY95-71 developed in the 1990s by the Wheat Research Institute of Sichuan Agricultural University is susceptible to prevalent Pt races in China. The susceptible control is Mingxian 169. Additionally, a high-resolution mapping population comprising $3619 \mathrm{~F}_{2}$ plants was constructed by crossing resistant line \#36 and susceptible line \#4 of the RIL population.

The wheat cultivar Selkirk was donated by Wentao Zhang, Gansu Academy of Agricultural Sciences, and RL6005 was provided by Dr. Minjie Liu, College of Plant Protection, Shanxi Agricultural University, China. A set of core germplasms containing 262 wheat varieties that are widely used in Chinese breeding programs (Chen et al. 2020) was used to detect the frequency of the $\mathrm{LrCH} 1539$ allele.

The pathotype of $P$. triticina was collected from the wheat-growing region in northern China through single spore separation and pure culturing. The Pt race was designated according to the system of Long and Kolmer (1989) and provided by Dr. Minjie Liu. A total of 31 races were used in the experiment (Table S1). The avir/vir formulas for THK were as follows: Lr3ka, Lr9, Lr13, Lr14b, Lr18, Lr21, Lr24, Lr25, Lr28, Lr29, Lr38/ Lr1, Lr2a, Lr2b, Lr2c, Lr3, Lr3bg, Lr10, Lr11, Lr12, Lr14a, Lr15, Lr16, Lr17, Lr20, Lr22a, Lr22b, Lr23, Lr26, Lr30, Lr32, Lr33, Lr36 and Lr39.

\section{Testing for seedling reactions}

In the greenhouse, resistance identification of the tested material and the susceptible control Mingxian 169 was carried out using Pt races at the seedling stage. Seeds were planted in a plastic growth chamber with five plants for each line and repeated twice. When the first leaves were fully expanded, inoculations were performed by dusting with urediniospores. Inoculated seedlings were subsequently incubated in the dark at $18^{\circ} \mathrm{C}$ and $100 \%$ relative humidity $(\mathrm{RH})$ for $24 \mathrm{~h}$. The seedlings were then placed in a growth chamber at $16-21^{\circ} \mathrm{C}$ and $70 \% \mathrm{RH}$. The infection types (ITs) were scored approximately 14 days later based on the 0-4 Stakman Scale modified by Roelfs et al. (1992). ITs: 0 = no visible symptoms; necrotic or chlorotic flecks without any uredinia; 1 = small uredinia surrounded by necrosis; 2 = small to medium uredinia surrounded by chlorotic or necrosis; $3=$ medium-sized uredinia without chlorosis or necrosis; 4 = large-sized uredinia without chlorosis or necrosis. "+" and "-" were used when uredinia were somewhat larger or smaller than normal for the ITs. ITs of 0-2 and 3-4 were considered resistant and susceptible, respectively (Kertho et al. 2015).

A chi-square $\left(\chi^{2}\right)$ test was used to determine whether the observed segregation ratio of the phenotypic data fits the expected genetic ratios. The $\chi^{2}$ analysis was performed in Microsoft Excel (version 2010) using the 'chitest' function to calculate the $\chi^{2}$ and $p$-value. 
The genomic DNA of all tested wheat lines was extracted using a modified CTAB method (Hill-Ambroz et al. 2002)

and detected by $1 \%$ agarose electrophoresis. The concentration was measured, and the DNA samples were diluted to a final concentration of $50 \mathrm{ng} / \mu \mathrm{L}$ and stored at $-20^{\circ} \mathrm{C}$ for later use.

BSA was performed to determine the chromosomal location of leaf rust resistance in $\mathrm{CH} 1539$. Equal amounts of DNA from 21 homozygous resistant RILs (HR, ITs: 0-1) and 21 homozygous susceptible RILs (HS, ITs: 3-4) were pooled to constitute the respective resistant and susceptible bulks. The two parents and bulks were genotyped with the wheat 35K DArTseq array (Diversity Arrays Technology Pty Ltd). Polymorphic SNPs between parents were considered to be associated with $\mathrm{LrCH} 1539$ when the score values of resistant bulk and $\mathrm{CH} 1539$, susceptible bulk and SY95-71 were consistent. The sequences of DArTseq markers linked to resistance were blasted against the genome assembly of T. aestivum cv. Chinese Spring (CS) [International Wheat Genome Sequencing Consortium (IWGSC) RefSeq v1.0, https://urgi.versailles.inra.fr/download/iwgsc/IWGSC_RefSeq_Annotations/v1.0/] (IWGSC 2018) to obtain their physical positions.

\section{SSR marker assays and genotyping}

Based on the results of polymorphic SNPs in the array, the specific-chromosome SSR primers were developed and named with the prefix "sxau" (Shanxi Agricultural University) followed by a consecutive number. A total of 157 designed markers and twelve markers linked with known Lrgenes were used to screen the parents and bulks to confirm their polymorphism before genotyping the entire RIL population, and the screened markers were then used to construct a linkage map. Another 120 specific chromosome markers were also designed for fine mapping LrCH1539. Information of the markers located on the linkage map in this paper is listed in Table S2.

PCR amplification was performed on a C1000 Touch thermal cycler. The PCR amplification reaction mixture volume was $10 \mu \mathrm{L}$ : $5.0 \mu \mathrm{L}$ of 2xTaq PCR Master Mix (Tiangen Biochemical Incorporation, Beijing), $2.0 \mu \mathrm{L}$ of dd $\mathrm{H}_{2} \mathrm{O}$, $1.0 \mu \mathrm{L}(2 \mathrm{mmol} / \mu \mathrm{L})$ of each primer, and $1.0 \mu \mathrm{L}(50 \mathrm{ng} / \mu \mathrm{L})$ of DNA template. PCR amplification program: predenaturation at $94^{\circ} \mathrm{C}$ for $5 \mathrm{~min}$; denaturation at $94^{\circ} \mathrm{C}$ for $30 \mathrm{~s}$, renaturation at $55-68^{\circ} \mathrm{C}$ (determined by the annealing temperature of each primer) for $30 \mathrm{~s}$, extension at $72^{\circ} \mathrm{C}$ for $60 \mathrm{~s}$, a total of 35 cycles; final extension at $72^{\circ} \mathrm{C}$ for 10 min and preservation at $12^{\circ} \mathrm{C}$. The PCR amplification products were detected by electrophoresis through $8 \%$ nondenaturing polyacrylamide gels (the mass ratio of Acr to Bis was 29:1) for 50-70 min. After silver nitrate staining and formaldehyde solution dyeing, the results were photographically observed.

\section{Genetic linkage map and gene annotation}

The linkage map for the CH1539/SY95-71 RIL population was constructed using the JoinMap v4.0 software (www.kyazma.nl), and the Kosambi map function was used to convert recombination rates to centimorgans (Kosambi 1943). A logarithm of odds (LOD) of 3.0 was set to declare genetic linkages. MapDraw V2.1 was used to draw the linkage map (Liu and Meng 2003).

The flanking markers were subjected to BLAST against IWGSC RefSeq v1.0 to obtain the physical location of the target gene. Then, gene annotation of the refined $\mathrm{LrCH} 1539$ interval was retrieved from the above mentioned IWGSC RefSeq v1.0. Expression data for the genes in leaf tissues and under pathogen treatment were obtained using the Wheat Expression Browser database (http://www.wheat-expression.com, Ramírez-González et al. 2018).

\section{Result}




\section{The reaction of parents and RILs to Pt races}

The parents $\mathrm{CH} 1539$ and SY95-71 and the RIL population were evaluated for their reactions to the Pt race THK at the seedling stage. $\mathrm{CH} 1539$ developed hypersensitive flecks with small- to medium-sized uredinia to the race THK, indicating a highly resistant reaction (Fig. 1); however, SY95-71 developed large-sized uredinia without chlorosis to THK, indicating a highly susceptible reaction (Fig. 1). The susceptible Mingxian 169 developed large-sized uredinia without chlorosis (Fig. 1).

Meanwhile, the RILs were segregated for their reaction to THK, and the reactions ranged from highly resistant $(I T=; 1)$ to highly susceptible (IT=4). Of the 184 RILs evaluated, 86 (two missing data) and 91 lines were resistant, and 96 and 93 lines were susceptible in the two duplications, respectively. The segregation of resistant and susceptible RILs fit a single gene segregation ratio of 1:1 (Table 1). Through the phenotypic analysis of the three groups of $F_{2}$ subpopulations, the separation of resistant lines and susceptible lines conformed to a separation ratio of 1:3 (Table 1), indicating that the resistance of $\mathrm{CH} 1539$ to Ptrace THK is controlled by a single recessive gene, tentatively named $\mathrm{LrCH} 1539$.

Table 1

The number of plants in response to $P t$ race THK in RILs derived from the cross $\mathrm{CH} 1539 \times \mathrm{SY} 95-71$ and three $\mathrm{F}_{2}$ groups $\left(F_{2}-1, F_{2}-2, F_{2}-3\right)$ derived from the cross lines $\# 36 \times \# 4$.

\begin{tabular}{|c|c|c|c|c|c|}
\hline \multirow[t]{2}{*}{ Group } & \multicolumn{2}{|c|}{ Resistance reaction } & \multirow[t]{2}{*}{ Theoretical ratio (R:S) } & \multirow[t]{2}{*}{$x^{2}$} & \multirow[t]{2}{*}{$P$ value } \\
\hline & $\mathbf{R}$ & $\mathrm{S}$ & & & \\
\hline RILs-rep1 & 86 & 96 & $1: 1$ & 0.71 & 0.60 \\
\hline RILs-rep2 & 91 & 93 & $1: 1$ & 3.00 & 0.91 \\
\hline$F_{2^{-1}}$ & 38 & 128 & $1: 3$ & 0.88 & 0.65 \\
\hline$F_{2}-2$ & 126 & 370 & $1: 3$ & 2.47 & 0.88 \\
\hline$F_{2}-3$ & 64 & 199 & $1: 3$ & 2.17 & 0.86 \\
\hline
\end{tabular}

\section{Molecular Mapping of LrCH1539}

A total of 106 SNPs showed polymorphisms between the DNA bulks after genotyping by the 35K DArTseq array. According to the physical location of the polymorphic SNPs, 60 (56.6\%) of these SNPs were located on chromosome 2B, and no more than 11 (10.4\%) were located on other single chromosomes (Fig. 2A). These results indicated that SNPs in $2 \mathrm{~B}$ were extremely likely to be associated with the resistance locus.

For the polymorphic SNPs distributed on chromosome 2B, the average number of polymorphic SNPs contained in each $10 \mathrm{Mb}$ was calculated using $10 \mathrm{Mb}$ as a sliding window. The obtained results showed that the most polymorphic SNPs in the physical range of $0-20 \mathrm{Mb}$ accounted for more than $78.3 \%$ (47) of polymorphic SNPs on 2B. (Fig. 2B). Therefore, it is speculated that there is a leaf rust resistance site at the end of the short arm of chromosome 2B. 
Chromosome-specific SSR markers in the region were developed and then screened on the parents and bulks to confirm polymorphisms before being genotyped on the entire population; 35 polymorphic markers were successful in distinguishing the contrasting parents and bulks. Among the 12 markers linked to known Lrgenes, one KASP and two SSR markers linked to Lr16 were also polymorphic between parents and bulks. A genetic map was constructed using one KASP and 16 SSR markers genotyped on the $184 \mathrm{~F}_{2: 10}$ individuals, resulting in a linkage group spanning $16.0 \mathrm{cM}$. LrCH1539 was preliminarily located between the SSR markers sxau-2BS81/Xwmc764 and sxau-2BS136 in an interval of $1.1 \mathrm{cM}$ and coseparated with sxau-2BS47 and 2BS-5175914_kwm849 (Fig. 3). According to the physical position of the markers sxau-2BS81 and sxau-2BS136 in the CS1.0 reference genome, LrCH1539 was located in the 2.4 Mb region between 5.7 and 8.1 Mb (Fig. 3).

\section{Fine mapping of $\mathrm{LrCH} 1539$}

To narrow down the region containing $\mathrm{LrCH} 1539$, we generated $3619 \mathrm{~F}_{2}$ individuals to screen for new crossovers between sxau-2BS81 and sxau-2BS136, and 33 crossovers were identified. Among the 33 crossovers, 12 showed recombination between the marker sxau-2BS136 and $\mathrm{LrCH} 1539$, while 21 showed recombination between the marker sxau-2BS81 and LrCH1539. Based on the 2.4 Mb interval of CS RefSeq v1.0, more primers were designed and tested on the contrasting parents and bulks. Four markers (sxau-Q2BS3, sxau-Q2BS5, sxau-2BS210, and sxau$2 B S 255)$ were polymorphic and used with sxau-2BS47 to examine 33 crossovers. The obtained results indicated that the closest flanking markers of $\mathrm{LrCH} 1539$ were sxau-2BS47 (with one recombination event) and sxau-2BS255 (with six recombination events), and the marker cosegregating with LrCH1539 was sxau-2BS210 (Fig. 4). These results suggest that the $\mathrm{LrCH} 1539$ locus is located in a $779.4 \mathrm{~kb}$ region between markers sxau-2BS47 and sxau$2 B S 255(6,226,584 \mathrm{bp}-7,005,940 \mathrm{bp})$ in CS RefSeq v1.0.

\section{Comparison with reported Lr genes in chromosome 2B}

The linked markers of the $L r$ gene reported on chromosome 2BS were used to detect contrasting parents and bulks (Table 2, Fig. S1). The obtained results showed that no polymorphisms of Xgwm630, Xbarc55, Xbarc7, sun471, and Sr39F2/R3 were observed between CH1539 and SY95-71, and none of the characteristic bands of Sr39F2/R3 were amplified. Xwmc770, Xgwm374, and Xgwm429b were polymorphic between parents, but they were not polymorphic between R-bulk and S-bulk. These results suggested that these markers were not linked to $\mathrm{LrCH} 1539$. 
Table 2

The reported $L$ rgenes on chromosome $2 \mathrm{BS}$ in wheat

\begin{tabular}{|c|c|c|c|c|c|c|c|}
\hline \multirow[t]{2}{*}{ Gene } & \multirow{2}{*}{$\begin{array}{l}\text { Genetic } \\
\text { method }\end{array}$} & \multirow{2}{*}{$\begin{array}{l}\text { Type of } \\
\text { resistance }\end{array}$} & \multirow[t]{2}{*}{ Source } & \multicolumn{3}{|c|}{ Linkage marker } & \multirow[t]{2}{*}{ Reference } \\
\hline & & & & Name & $\begin{array}{l}\text { Polymorphism } \\
\text { in parents }\end{array}$ & $\begin{array}{l}\text { Linked to } \\
\text { phenotype }\end{array}$ & \\
\hline \multirow[t]{3}{*}{ Lr13 } & \multirow{3}{*}{$\begin{array}{l}\text { recessive } \\
\text { partially } \\
\text { dominant }\end{array}$} & APR & $\begin{array}{l}\text { common } \\
\text { wheat }\end{array}$ & Xbarc55 & No & No & $\begin{array}{l}\text { Zhang et } \\
\text { al. } 2016\end{array}$ \\
\hline & & & & Xbarc7 & No & No & $\begin{array}{l}\text { Dyck et } \\
\text { al. } 1966\end{array}$ \\
\hline & & & & Xgwm630 & No & No & $\begin{array}{l}\text { Seyfarth } \\
\text { et al. } \\
2000\end{array}$ \\
\hline \multirow[t]{2}{*}{ Lr16 } & $\mathrm{N}$ & ASR & $\begin{array}{l}\text { common } \\
\text { wheat }\end{array}$ & $X w m c 764$ & Yes & Yes & $\begin{array}{l}\text { Kassa et } \\
\text { al. } 2017\end{array}$ \\
\hline & & & & Xwmc661 & Yes & Yes & \\
\hline$L r 23$ & $\begin{array}{l}\text { recessive } \\
\text { partially } \\
\text { dominant }\end{array}$ & ASR & $\begin{array}{l}\text { durum } \\
\text { wheat }\end{array}$ & Xsun471 & No & No & $\begin{array}{l}\text { Chhetri et } \\
\text { al. } 2017 \\
\text { Mclntosh } \\
\text { and Dyck, } \\
1975\end{array}$ \\
\hline Lr35 & $\mathrm{N}$ & APR & $\begin{array}{l}T . \\
\text { speltoides }\end{array}$ & Sr39F2/R3 & No & No & $\begin{array}{l}\text { Gold et } \\
\text { al. } 1999\end{array}$ \\
\hline Lr48 & Recessive & APR & $\begin{array}{l}\text { common } \\
\text { wheat }\end{array}$ & Xgwm429b & Yes & No & $\begin{array}{l}\text { Saini et } \\
\text { al. } 2002 \\
\text { Bansal et } \\
\text { al. } 2008\end{array}$ \\
\hline LrA2K & $\mathrm{N}$ & ASR & $\begin{array}{l}\text { common } \\
\text { wheat }\end{array}$ & $X w m c 770$ & Yes & No & $\begin{array}{l}\text { Sapkota } \\
\text { et al. } \\
2019\end{array}$ \\
\hline LrZH22 & dominant & ASR & $\begin{array}{l}\text { common } \\
\text { wheat }\end{array}$ & Xgwm374 & Yes & No & $\begin{array}{l}\text { Wang et } \\
\text { al. } 2016\end{array}$ \\
\hline LrCH1539 & Recessive & ASR & $\begin{array}{l}\text { common } \\
\text { wheat }\end{array}$ & & & & \\
\hline
\end{tabular}

LrCH1539 has a genetic distance of $0.8 \mathrm{cM}$ from Xwmc764, cosegregated with KASP marker 2BS-

$5175914 \_k w m 849$ (Fig. 3), and has a linkage relationship with CAPS markers kwm847and dCAPS markers kwm747transformed from KASP markers 2BS-5175914_kwm847 and 2BS-5194460_kwm747, respectively (Fig. S1).

\section{Resistance spectrum analysis of LrCH1539 and Lr16}

The wheat accessions CH1539 and RL6005 showed different disease responses to 31 Chinese Pt races (Fig. 5, Table S1). Twelve of 31 Ptraces, including DHK, FHK, FKT, KHJ, PGL, PHS, PKJ, PKT, PRK, PTK, THK, and TKK, 
were avirulent to $\mathrm{LrCH} 1539$ but virulent to $\mathrm{Lr} 16$ (Fig. 5). The race PBB was avirulent to $L r 16$ but virulent to LrCH1539.

\section{Distribution of the $\mathrm{LrCH} 1539$ allele in wheat varieties}

The cosegregating marker sxau-2BS210 of $\mathrm{LrCH} 1539$ had genotyped 262 varieties which are widely used as core germplasms in Chinese breeding programs. Only $12(4.6 \%)$ of these varieties showed the presence of the resistant $\mathrm{CH} 1539$ allele, and the rest showed the presence of the susceptible SY95-71 allele. These 12 wheat varieties include two Italian varieties (Funo and St2422/464) and ten Chinese varieties (Laomai, Hongmangmai, Yangmai158, Kelao 4, Ji'nan 17, Xiaoyan 6, Shaannong 7859, Fan 6, Zhengmai 9023, Yanzhan 1) (Fig. 6).

\section{Discussion}

The wheat accession $\mathrm{CH} 1539$ is a valuable source of genetic variation for biotic resistance, such as powdery mildew and stripe rust resistance (data not shown), and has a high level of resistance to leaf rust in the field. In this study, the recessive seedling resistance gene $\mathrm{LrCH} 1539$ was characterized on the short arm of chromosome 2B in $\mathrm{CH} 1539$.

Previous studies have identified several permanently and tentatively designated $L r$ genes on chromosome 2BS, including $L r 13, L r 16, L r 23, L r 35, L r 48, L r 73, L r Z H 22$, and $L r A 2 K$. Based on the integrated genetic maps (Maccaferri et al. 2015), the markers flanked or linked with the reported genes were far from Xwmc764 and Xwmc661, which were flanked to $\mathrm{LrCH} 1539$ (Fig. 7A). Meanwhile, there was no linkage relationship between these markers and $L r C H 1539$ (Table 2, Fig. S1), which indicates that the genes $L r 13, L r 23, L r 48, L r Z H 22$, and $L r A 2 K$ are distinct from $L r C H 1539$. $L r 35$ is an adult-plant resistance gene located on a translocation chromosome fragment extracted from Aegilops speltoides (Gold et al. 1999). The selection marker Sr39F2/R3 of Lr35 could not be amplified in CH1539, and there is no Triticum speltoides in the pedigree of $\mathrm{CH} 1539$. Therefore, $\mathrm{LrCH} 1539$ cannot be $\mathrm{Lr} 35$.

The dominant gene Lr73 is located between XwPt-4453 and XwPt-8760 on 2BS (Park et al. 2014), and its genetic position overlaps with $L r C H 1539$ (Fig. $7 A$ ). The gene $L r 73$, sometimes referred to as the "fossil" gene, only exists in Morocco and some other Australian wheat cultivars (Park et al. 2014); thus, it is considered not to exist in the Chinese wheat background. Furthermore, unlike $\mathrm{Lr} 73, \mathrm{LrCH} 1539$ in this study is a recessive gene.

The molecular markers coseparated with $L r 16$ are also linked or coseparated with $L r C H 1539$. Meanwhile, on the physical map, $L r C H 1539$ is included in the region of $L r 16$ (Fig. 7B). CH1539, RL6005, and Selkirk were genotyped and analyzed with markers sxau-2BS210, sxau-2BS255, sxau-2BS47, sxau-Q2BS3, sxau-Q2BS5, kwm847, and $k w m 747$ (Table S3). According to the genotyping results of three genotypes with seven markers, CH1539, RL6005, and Selkirk had the same haplotype (combination of marker alleles). Therefore, $\mathrm{LrCH} 1539$ and $\mathrm{Lr16}$ may be in the same chromosome interval.

However, the original sources of $L r 16$ are believed to be five wheat cultivars, Warden, Exchange, Selkirk, Etoile de Choisy, and Columbus (Harrison et al. 2015), while the pedigree of $\mathrm{CH} 1539$ does not correlate with Lr16. $\mathrm{CH} 1539$ and RL6005 produced different LR resistance responses to 13 Ptraces, including THK. It is assumed that the differences in the response of $\mathrm{CH} 1539$ and RL6005 to leaf rust are not only due to differences in the genetic background but may also result from differences in the candidate genes for $\mathrm{LrCH} 1539$ and $\mathrm{Lr} 16$. 
The wheat core germplasms were genotyped using the cosegregating marker sxau-2BS210 of $\mathrm{LrCH} 1539$; the CH1539 allele was detected in 12 cultivars, and the remaining 250 cultivars were the SY95-71 allele. Of the 12 cultivars, Funo and St2422/464 are Italian varieties introduced in China in the 1950s and 1970s, respectively, and have been widely used as parents in breeding programs. Five of eight Chinese wheat varieties, Yangmai 158, Xiaoyan 6, Fan 6, Zhengmai 9023, and Yanzhan 1, all have Funo and/or St2422/464 genetic backgrounds (Wu et al. 1993; Xu et al. 2009; Yuan et al. 1981; Zou 1991). The remaining two varieties, Laomai and Hongmangmai, are Chinese landraces. The former is distributed in Shaanxi Province, China, and the latter is distributed in Shandong, Hebei, and Shanxi provinces. In summary, the $\mathrm{CH} 1539$ allele of $\mathrm{LrCH} 1539$ is distributed over a wide range but at a very small frequency, representing only $4.6 \%$ of the tested germplasms. Among the 12 detected germplasms, three (25\%) had a "Funo" genetic background, and four (33.3\%) had a "St2422/464" genetic background. Therefore, the $\mathrm{CH} 1539$ allele of $\mathrm{LrCH} 1539$ has good application potential.

LrCH1539 was mapped to 6,226,584-7,005,940 bp on chromosome arm 2BS (Chinese Spring RefSeq v.1.0). There were 42 annotated genes in this region, including 14 low confidence genes and 28 high confidence genes (IWGSC 2018). To predict the $\mathrm{LrCH} 1539$ gene, we analyzed the expression profiles of genes in the candidate region after being induced by pathogens using the wheat expVIP expression platform. Since symptoms of LR resistance begin from the early seedling stage and are maintained to the adult stage, we hypothesized that the $\mathrm{LrCH} 1539$ allele should be expressed in leaves throughout the entire growth period. Nine of 42 candidate genes were expressed (above two transcripts per million) in at least ten RNA-seq samples (leaves and stress-disease, $n=99$ ) at different developmental stages (Table S4). Eight of the nine expressed genes were high-confidence genes, which may be related to plant disease resistance.

Gene annotation of the corresponding region in Chinese Spring revealed that the gene TraesCS2B01G012400 encodes the Avr9/Cf-9 rapidly elicited protein, which is a protein produced after the plant resistance gene Cf- 9 recognizes pathogens and plays a pivotal role during plant defense responses (Rowland et al. 2005; van den Burg et al. 2008). The gene TraesCS2B01G012600 encodes the StAR-related lipid transfer protein (LTP), and LTP has been classified as a member of the pathogenesis-related (PR) proteins belonging to the PR-14 group (Van Loon et al. 1999). Overexpression of LTP genes enhances resistance to plant pathogens and plays an important role in plant long-distance systemic signaling in tobacco (Sarowar et al. 2009). McLaughlin et al. (2015) found that LTP can increase the glutathione content and enhance Arabidopsis resistance to a trichothecene mycotoxin; Kirubakaran et al. (2008) identified a new antifungal lipid transfer protein from wheat. Li et al. (2006) used the transient overexpression method to study the role of cloned LTP1 in wheat-powdery mildew interactions, and the obtained results indicated obvious effectiveness of LTP1 in powdery mildew resistance. The gene TraesCS2B01G012800 encodes a peptidyl-prolyl cis-trans isomerase. The activity domain of this enzyme is a common feature of immunophilins that are ubiquitous in organisms (Fisher et al. 1989). Pogorelko et al. (2014) characterized three Arabidopsis thaliana immunophilin genes involved in the plant defense response against Pseudomonas syringae, and the research showed that Arabidopsis knock-out mutations in these immunophilins result in an increased susceptibility to $P$. syringae, whereas overexpression of these genes alters the transcription profile of pathogen-related defense genes and led to enhanced resistance. These genes are essential in the biotic stress response of plant resistance to pathogens. However, based on the available data, we cannot determine the LrCH1539 gene, which requires more experimental evidence.

\section{Conclusions}


A recessive seedling stage $L R$ resistance gene, $\mathrm{LrCH} 1539$, located within a $779.4 \mathrm{~kb}$ physical region $(6,226,584 \mathrm{bp}-$

$7,005,940 \mathrm{bp}$ ) on 2BS, was characterized in wheat accession $\mathrm{CH} 1539$, and the cosegregating marker sxau-2BS210 was developed. $\mathrm{LrCH} 1539$ and $\mathrm{Lr16}$ are at the same position on the chromosome but differ in their resistance spectra.

\section{Declarations}

Author contribution DS performed the experiments; DS and LQ analyzed the data, carried out the bioinformatics work and wrote the manuscript; XZ and ZC conceived and supervised the experiments; XZ and XL administrated the project; LC, HG, SZ and FC investigated the phenotype; ZC revised the manuscript. All authors have read and approved the final manuscript.

Funding This work was supported by the Shanxi Province S \& T Cooperation and Exchange Special Program; the State Key Laboratory of Integrative Sustainable Dryland Agriculture (in preparation), Shanxi Agricultural University (202002-3); the Key Science \& Technology Project in Shanxi Province (201903D211003-2); and the Biological Breeding Engineering (YZGC093).

Ethics approval Not applicable.

Consent to participate Not applicable.

Consent for publication Not applicable.

Conflict of interest The authors declare no competing interests.

Supplementary information The online version contains supplementary material available at XXXX.

\section{References}

1. Bansal UK, Hayden MJ, Venkata BP, Khanna R, Saini RG, Bariana HS (2008) Genetic mapping of adult plant leaf rust resistance genes $L r 48$ and $L r 49$ in common wheat. Theor Appl Genet 117:307-312. https://doi.org/10.1007/s00122-008-0775-6

2. Chen F, Jia H, Zhang X, Qiao L, Li X, Zheng J, Guo H, Powers C, Yan L, Chang Z (2019) Positional cloning of $\mathrm{PmCH} 1357$ reveals the origin and allelic variation of the Pm2 gene for powdery mildew resistance in wheat. Crop J 7(6):771-783. https://doi.org/10.1016/j.cj.2019.08.004

3. Chhetri M, Bariana H, Wong D, Sohail Y, Hayden M, Bansal U (2017) Development of robust molecular markers for marker-assisted selection of leaf rust resistance gene $L r 23$ in common and durum wheat breeding programs. Mol Breeding 37:21. https://doi.org/10.1007/s11032-017-0628-6

4. Cloutier S, McCallum BD, Loutre C, Banks TW, Wicker T, Feuillet C, Keller B, Jordan MC (2007) Leaf rust resistance gene $L r 1$, isolated from bread wheat (Triticum aestivum L.) is a member of the large psr567 gene family. Plant Mol Biol 65:93-106. https://doi.org/10.1007/s11103-007-9201-8

5. Dyck PL, Samborski DJ, Anderson RG (1966) Inheritance of adult-plant leaf rust resistance derived from the common wheat varieties exchange and Frontana. Can J Genet Cytol 8(4):665-671.

https://doi.org/10.1139/g66-082

Page $10 / 20$ 
6. Ellis JG, Lagudah ES, Spielmeyer W, Dodds PN (2014) The past, present and future of breeding rust resistant wheat. Front Plant Sci 5:641. https://doi.org/10.3389/fpls.2014.00641

7. Feuillet C, Travella S, Stein N, Albar L, Nublat A, Keller B (2003) Map-based isolation of the leaf rust disease resistance gene $L r 10$ from the hexaploid wheat (Triticum aestivum L.) genome. Proc Natl Acad Sci USA 100(25):15253-15258. https://doi.org/10.1073/pnas.2435133100

8. Fisher G, Wittmann-Liebold B, Lang K, Kiefhaber T, Schmid FX (1989) Cyclophilin and the peptidyl-prolyl cistrans isomerase are probably identical proteins. Nature 337:476-478. https://doi.org/10.1038/337476a0

9. Gao P, Zhou Y, Gebrewahid TW, Zhang P, Yan X, Li X, Yao Z, Li Z, Liu D (2019) Identification of known leaf rust resistance genes in common wheat cultivars from Sichuan province in China. Crop Prot 115:122-129. https://doi.org/10.1016/j.cropro.2018.09.012

10. Gold J, Harder D, Townley-Smith F, Aung T, Procunier J (1999) Development of a molecular marker for rust resistance genes Sr39 and Lr35 in wheat breeding lines. Electron J Biotechnol 2(1):35-40. doi: 10.2225/vol2issue1-fulltext-1

11. Harrison NR, Fritz AK, Glasscock JI, Ahmed S, Messina DN, Amand PS, Fellers JP (2015) Using RNA sequencing and in silico subtraction to identify resistance gene analog markers for $L r 16$ in wheat. Plant Genome 8(2). https://doi.org/10.3835/plantgenome2014.08.0040

12. Hill-Ambroz KL, Brown-Guedira GL, Fellers JP (2002) Modified rapid DNA extraction protocol for high throughput microsatellite analysis in wheat. Crop Sci 42(6):2088-2091. doi:10.2135/cropsci2002.2088

13. Huang L, Brooks SA, Li W, Fellers JP, Trick HN, Gill BS (2003) Map-based cloning of leaf rust resistance gene Lr21 from the large and polyploid genome of bread wheat. Genetics 164(2):655-664. doi:

10.1093/genetics/164.2.655

14. Huerta-Espino J, Singh RP, Germán S, McCallum BD, Park RF, Chen WQ, Bhardwaj SC, Goyeau H (2011) Global status of wheat leaf rust caused by Puccinia triticina. Euphytica 179:143-160.

https://doi.org/10.1007/s10681-011-0361-x

15. Kassa MT, You FM, Hiebert CW, Pozniak CJ, Fobert PR, Sharpe AG, Menzies JG, Humphreys DG, Harrison NR, Fellers JP, McCallum BD, McCartney CA (2017) Highly predictive SNP markers for efficient selection of the wheat leaf rust resistance gene Lr16. BMC Plant Biol 17:45. https://doi.org/10.1186/s12870-017-0993-7

16. Kertho A, Mamidi S, Bonman JM, McClean PE, Acevedo M (2015) Genome-wide association mapping for resistance to leaf and stripe rust in winter-habit hexaploid wheat landraces. PLoS ONE 10(6):e0129580. https://doi.org/10.1371/journal.pone.0129580

17. Kirubakaran SI, Begum SM, Ulaganathan K, Sakthivel N (2008) Characterization of a new antifungal lipid transfer protein from wheat. Plant Physiol Biochem 46(10):918-927.

https://doi.org/10.1016/j.plaphy.2008.05.007

18. Kolmer JA (2005) Tracking wheat rust on a continental scale. Curr Opin Plant Biol 8:441-449. https://doi.org/10.1016/j.pbi.2005.05.001

19. Kolodziej MC, Singla J, Sánchez-Martín J, Zbinden H, Šimková H, Karafiátová M, Doležel J, Gronnier J, Poretti M, Glauser G, Zhu W, Köster P, Zipfel C, Wicker T, Krattinger SG, Keller B (2021) A membrane-bound ankyrin repeat protein confers race-specific leaf rust disease resistance in wheat. Nat Commun 12:956.

https://doi.org/10.1038/s41467-020-20777-x

20. Kosambi DD (1943) The estimation of map distances from recombination values. Ann Eugen 12:172-175 
21. Krattinger SG, Lagudah ES, Spielmeyer W, Singh RP, Huerta-Espino J, McFadden H, Bossolini E, Selter LL, Keller $B$ (2009) A putative ABC transporter confers durable resistance to multiple fungal pathogens in wheat. Science 323(5919):1360-1363. doi: 10.1126/science.1166453

22. Kumar S, Bhardwaj SC, Gangwar OP, Sharma A, Qureshi N, Kumaran VV, Khan H, Prasad P, Miah H, Singh GP, Sharma K, Verma H, Forrest KL, Trethowan RM, Bariana HS, Bansal UK (2021) Lr80: A new and widely effective source of leaf rust resistance of wheat for enhancing diversity of resistance among modern cultivars. Theor Appl Genet 134:849-858. https://doi.org/10.1007/s00122-020-03735-5

23. Li A, Meng C, Zhou R, Ma Z, Jia J (2006) Assessment of lipid transfer protein (LTP1) gene in wheat powdery mildew resistance. Agric Sci China 5(4):241-249. https://doi.org/10.1016/S1671-2927(06)60045-X

24. Li ZF, Xia XC, He ZH, Li X, Zhang LJ, Wang HY, Meng QF, Yang WX, Li GQ, Liu DQ (2010) Seedling and slow rusting resistance to leaf rust in Chinese wheat cultivars. Plant Dis 94(1):45-53.

https://doi.org/10.1094/PDIS-94-1-0045

25. Li ZF, Lan CX, He ZH, Singh RP, Rosewarne GM, Chen XM, Xia XC (2014) Overview and application of QTL for adult plant resistance to leaf rust and powdery mildew in wheat. Crop Sci 54:1907-1925.

https://doi.org/10.2135/cropsci2014.02.0162

26. Liu RH, Meng JL (2003) MapDraw: a Microsoft Excel macro for drawing genetic linkage maps based on given genetic linkage data. Hereditas (Beijing) 25(3):317-321 (In Chinese)

27. Long DL, Kolmer JA (1989) A North American system of nomenclature for Puccinia recondita f. sp. tritici. Phytopathology 79:525-529. doi: 10.1094/Phyto-79-525

28. Maccaferri M, Zhang J, Bulli P, Abate Z, Chao S, Cantu D, Bossolini E, Chen X, Pumphrey M, Dubcovsky J (2015) A genome-wide association study of resistance to stripe rust (Puccinia striiformis f. sp. tritici) in a worldwide collection of hexaploid spring wheat (Triticum aestivum L.). G3 5. 449-465.

https://doi.org/10.1534/g3.114.014563. 3

29. McCartney CA, Somers DJ, McCallum BD, Thomas J, Humphreys DG, Menzies JG, Brown PD (2005) Microsatellite tagging of the leaf rust resistance gene $L r 16$ on wheat chromosome 2BSc. Mol Breeding 15:329-337. https://doi.org/10.1007/s11032-004-5948-7

30. Mclntosh RA, Dyck PL (1975) Cytogenetical studies in wheat. VII. gene Lr23 for reaction to Puccinia recondita in Gabo and related cultivars. Aust J Biol Sci 28(2):201-211. doi:10.1071/bi9750201

31. McLaughlin JE, Bin-Umer MA, Widiez T, Finn D, McCormick S, Tumer NE (2015) A lipid transfer protein increases the glutathione content and enhances Arabidopsis resistance to a trichothecene mycotoxin. PLoS ONE 10(6):e0130204. https://doi.org/10.1371/journal.pone.0130204

32. Moore JW, Herrera-Foessel S, Lan C, Schnippenkoetter W, Ayliffe M, Huerta-Espino J, Lillemo M, Viccars L, Milne R, Periyannan S, Kong X, Spielmeyer W, Talbot M, Bariana H, Patrick JW, Dodds P, Singh R, Lagudah E (2015) A recently evolved hexose transporter variant confers resistance to multiple pathogens in wheat. Nat Genet 47:1494-1498. https://doi.org/10.1038/ng.3439

33. Park RF, Mohler V, Nazari K, Singh D (2014) Characterisation and mapping of gene Lr73 conferring seedling resistance to Puccinia triticina in common wheat. Theor Appl Genet 127. https://doi.org/10.1007/s00122-0142359-y. :2041-2049

34. Pink DA (2002) Strategies using genes for non-durable disease resistance. Euphytica 124:227-236. https://doi.org/10.1023/A:1015638718242 
35. Pogorelko GV, Mokryakova M, Fursova OV, Abdeeva I, Piruzian ES, Bruskin SA (2014) Characterization of three Arabidopsis thaliana immunophilin genes involved in the plant defense response against Pseudomonas syringae. Gene 538(1):12-22. https://doi.org/10.1016/j.gene.2014.01.029

36. Ramírez-González RH, Borrill P, Lang D et al (2018) The transcriptional landscape of polyploid wheat. Science 361(6403):eaar6089. doi: 10.1126/science.aar6089

37. Ren XL, Liu TG, Liu B, Gao L, Chen WQ (2015) Postulation of seedling leaf rust resistance genes in 84 Chinese winter wheat cultivars. J Integr Agric 14(10):1992-2001

38. Roelfs AP, Singh RP, Saari EE (1992) Rust diseases of wheat: Concepts and methods of disease management. CIMMYT, Mexico, D.F.

39. Rowland O, Ludwig AA, Merrick CJ, Baillieul F, Tracy FE, Durrant WE, Fritz-Laylin L, Nekrasov V, Sjölander K, Yoshioka H, Jones JD (2005) Functional analysis of Avr9/Cf-9 rapidly elicited genes identifies a protein kinase, ACIK1, that is essential for full Cf-9-dependent disease resistance in tomato. Plant Cell 17(1):295-310. doi: 10.1105/tpc.104.026013

40. Saini RG, Kaur M, Singh B, Sharma S, Nanda GS, Nayar SK, Gupta AK, Nagarajan S (2002) Genes Lr48 and Lr49 for hypersensitive adult plant leaf rust resistance in wheat (Triticum aestivum L.). Euphytica 124:365370. https://doi.org/10.1023/A:1015762812907

41. Sapkota S, Hao Y, Johnson J, Lopez B, Bland D, Chen Z, Sutton S, Buck J, Youmans J, Mergoum M (2019) Genetic mapping of a major gene for leaf rust resistance in soft red winter wheat cultivar AGS 2000. Mol Breeding 39:8. https://doi.org/10.1007/s11032-018-0909-8

42. Sarowar S, Kim YJ, Kim KD, Hwang BK, Ok SH, Shin JS (2009) Overexpression of lipid transfer protein (LTP) genes enhances resistance to plant pathogens and LTP functions in long-distance systemic signaling in tobacco. Plant Cell Rep 28:419-427. https://doi.org/10.1007/s00299-008-0653-3

43. Seyfarth R, Feuillet C, Schachermayr G, Messmer M, Winzeler M, Keller B (2000) Molecular mapping of the adult-plant leaf rust resistance gene Lr13 in wheat (Triticum aestivum L.). Journal of Genetics and Breeding 54(3):193-198

44. Thind AK, Wicker T, Šimková H, Fossati D, Moullet O, Brabant C, Vrána J, Doležel J, Krattinger SG (2017) Rapid cloning of genes in hexaploid wheat using cultivar-specific long-range chromosome assembly. Nat Biotechnol 35:793-796. https://doi.org/10.1038/nbt.3877

45. van den Burg HA, Tsitsigiannis DI, Rowland O, Lo J, Rallapalli G, Maclean D, Takken FL, Jones JD (2008) The F-box protein ACRE189/ACIF1 regulates cell death and defense responses activated during pathogen recognition in tobacco and tomato. Plant Cell 20(3):697-719. https://doi.org/10.1105/tpc.107.056978

46. Van Loon LC, Van Strien EA (1999) The families of pathogenesis-related proteins, their activities and comparative analysis of PR-1 type proteins. Physiol Mol Plant Pathol 55(2):85-97.

https://doi.org/10.1006/pmpp.1999.0213

47. Wang C, Yin G, Xia X, He Z, Zhang P, Yao Z, Qin J, Li Z, Liu D (2016) Molecular mapping of a new temperaturesensitive gene $\mathrm{LrZH} 22$ for leaf rust resistance in Chinese wheat cultivar Zhoumai 22. Mol Breeding 36:18. https://doi.org/10.1007/s11032-016-0437-3

48. Wu J, Gu SY, Xing YZ, Qian J (1993) The wheat cultivar Yangmai 158.Seed Science and Technology. (05):45. (In Chinese)

49. Xu WG, Hu L, Wang GS, Zhang L, Dong HB, Li Y, Zhang JY, Zan XC, Qi XL, Li CX, Zhao MZ (2009) Breeding strategies of high quality and wide regional adaptability wheat variety Zhengmai 9023 and relevant thoughts

Page 13/20 
on wheat high yield breeding.Journal of Henan Agricultural Sciences(09):14-18. (In Chinese)

50. Zhang P, Hiebert CW, McIntosh RA, McCallum BD, Thomas JB, Hoxha S, Singh D, Bansal U (2016) The relationship of leaf rust resistance gene $L r 13$ and hybrid necrosis gene $N e 2 m$ on wheat chromosome 2BS. Theor Appl Genet 129:485-493. https://doi.org/10.1007/s00122-015-2642-6

51. Zhang L, Xiao Y, Gao Y, Zhao N, An Y, Yang W, Meng Q, Yan H, Liu D (2020) Race and virulence analysis of Puccinia triticina in China during 2011 to 2013. Plant Dis 104:2095-2101. https://doi.org/10.1094/PDIS-0120-0047-RE

52. Zhao LN, Ren XD, Hu YY, Zhang N, Yang WX, Liu DQ (2013) Evaluation of wheat leaf rusts resistance of 23 Chinese wheat mini-core collections. Scientia Agricultura Sinica 46(3):441-450. doi: 10.3864/j.issn.05781752.2013.03.001(In Chinese)

53. Zou YL (1991) Breeding of sister lines of high-yield and rust-resistant wheat variety 'Fan 6'.Journal of Yibin University(01):1-8, 34. (In Chinese)

\section{Figures}

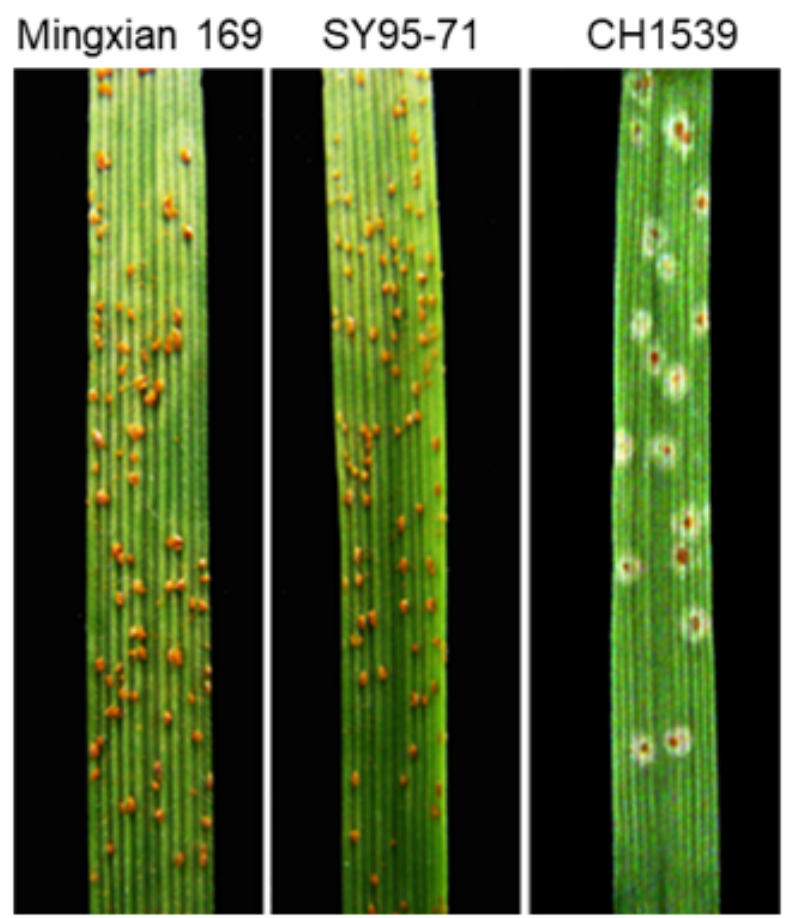

Figure 1

The phenotype of resistant parent $\mathrm{CH} 1539$, susceptible parent SY95-71, and susceptible control Mingxian 169 about 14 days after inoculation with Ptrace THK. 


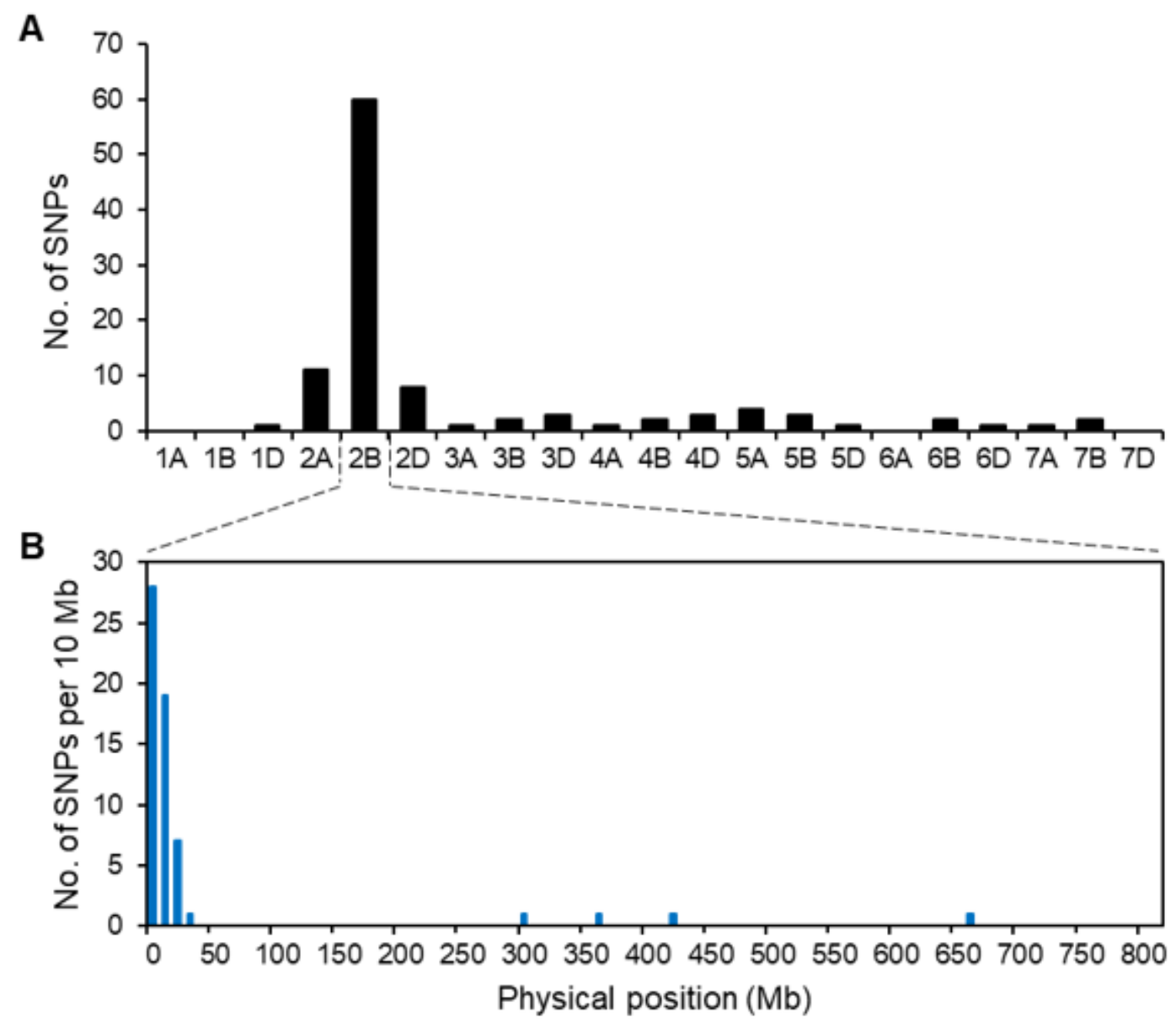

Figure 2

Distributions of the polymorphic SNPs in each chromosome by 35K DArTseq array $(\mathbf{A})$ and positions of SNPs in chromosome 2B (B). 


\section{CH1539/SY95-71}

2BS genetic map

\section{cM}

0.0

1.1

- $2 \mathrm{BS} 110$

sxau-2BS116

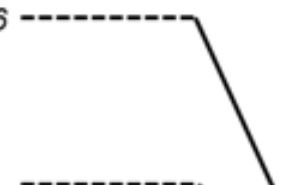

sxau-2BS60

$X w m c 764$

5.4

6.2

sxau-2BS81

LrCH1539

6.5

6.8

6.9

7.5

7.7

9.1
9.3

9.3

13.0

2BS-5175914_kwm849

$\longrightarrow$

fxau-2BS47

sxau-2BS47 --------

sxau-2BS136

$X$ wmc661

sxau-2BS11

sxau-2BS24

sxau-2BS26

sxau-2BS2 3

sxau-2BS32

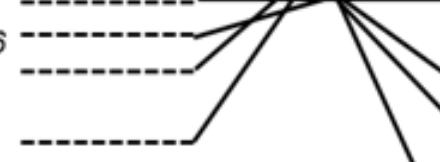

16.0
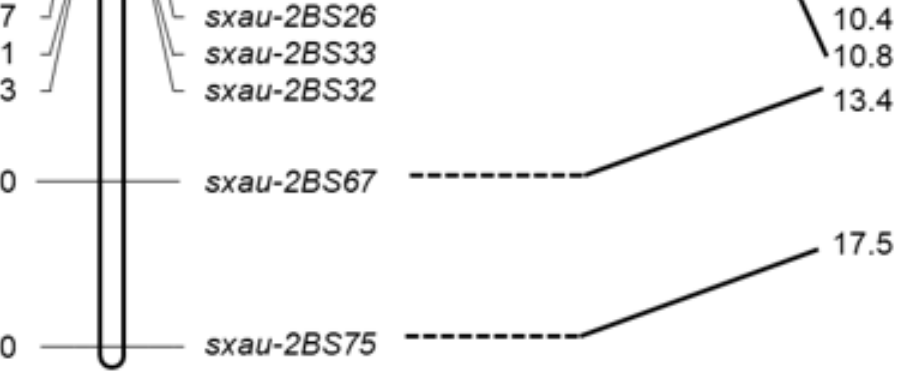

IWGSC CS1.0

\section{BS physical map}

Mb

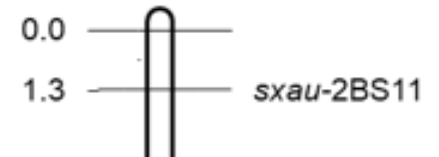

\begin{tabular}{l|l}
$2.5-5 x a u-2 B S 24$ \\
$3.3-$ & \\
sxau-2BS26
\end{tabular}

$3.5-{ }_{\text {Wmmc661 }}$

$4.4-$ sxau-2BS32

4.5

5.7

$6.2] \quad\left[\begin{array}{l}\text { sxau-2B136 } \\ \text { sxau-2BS47 }\end{array}\right.$

6.3 2BS-5175914_kwm849

sxau-2BS81

Xwmc764

sxau-2BS60

sxau-2B110

sxau-2B116

7.5

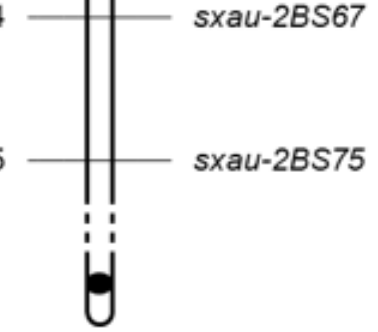

\section{Figure 3}

Genetic map of wheat chromosome 2BS showing the location of leaf rust resistance gene $\mathrm{LrCH} 1539$. The 2BS physical map was based on the IWGSC CS1.0 genomic sequence. 


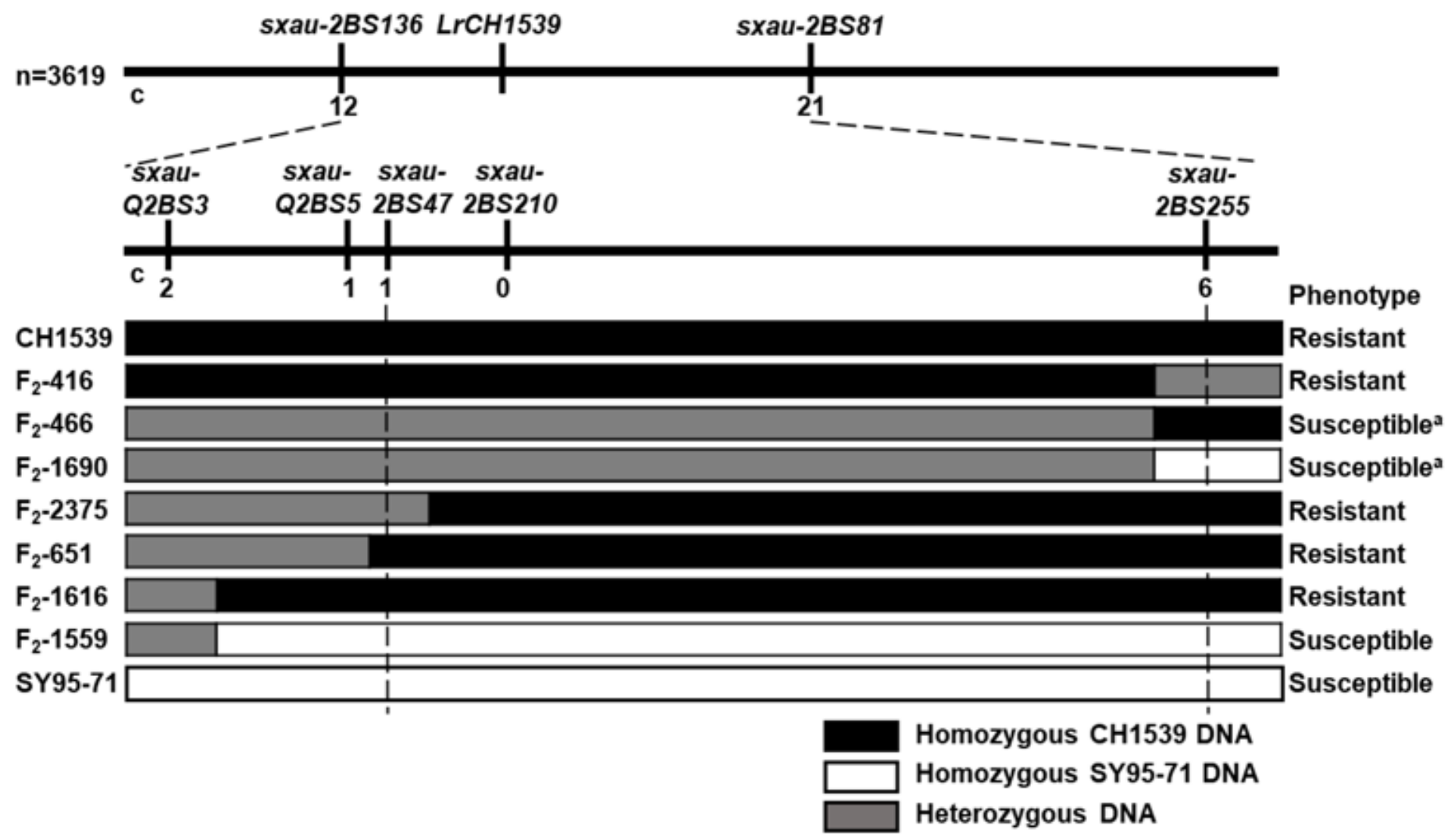

Figure 4

Fine mapping of $L r C H 1539$. Phenotypes and genotypes of seven $F_{2}$ crossovers (including $F_{2}-416, F_{2}-466, F_{2}-1690$, $\left.F_{2}-2375, F_{2}-651, F_{2}-1616, F_{2}-1559\right)$ are showed. The name and phenotype of $F_{2}$ individuals were labeled in the left and right, respectively. Black, white, and gray blocks present genomic regions of $\mathrm{CH} 1539$, SY95-71 and heterozygous, respectively. a: The phenotype of $\mathrm{F}_{2: 3}$ lines was segregated. c: indicated the number of crossovers.

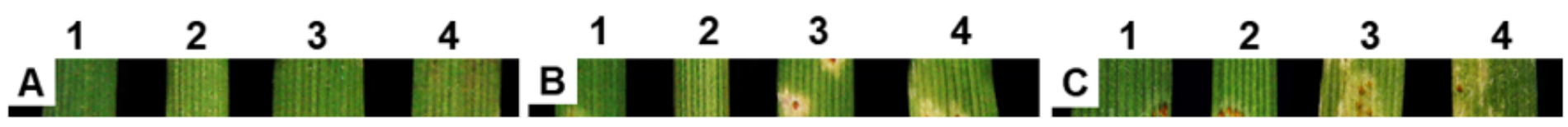

Figure 5 
Phenotype of susceptible parent SY95-71 (1), RL6005 carried with Lr16 (2), resistant parent CH1539 (3), and the resistant line \#72 (4) after inoculation with Pt race KHJ (A), PHS(B), PKJ(C), PKT(D) and PRK(E).

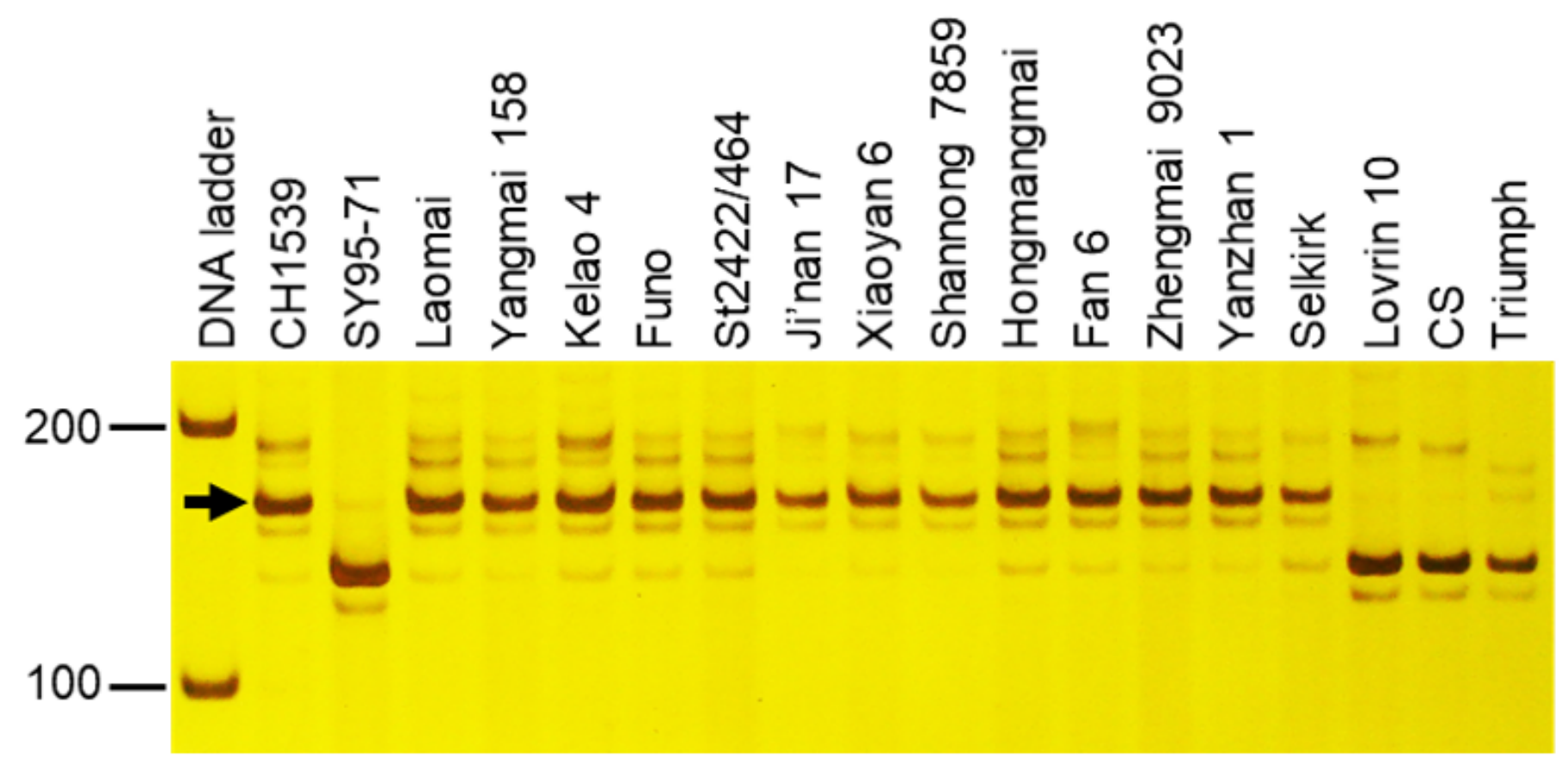

Figure 6

PCR profiles of the marker sxau-2BS210 co-separated with $\mathrm{LrCH} 1539$ in several Chinese core germplasms in breeding programs. The arrowhead indicated co-segregating PCR amplicons linked to $\mathrm{LrCH} 1539$. Numbers on the left are the size in bp of the DNA ladder. 
Lr16 (Kassa et al. 2017)

Lr23 (Chhetri et al. 2017)

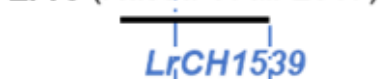

Lr73 (Park et al. 2014)
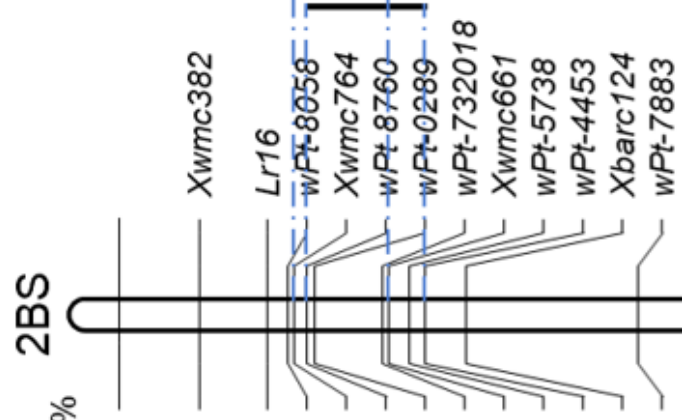

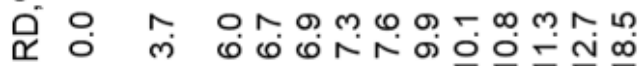

\section{LrZH22 (Wang et al. 2016)}

LrA2K (Sapkota et al. 2019)

Lr13 (Seyfarth et al. 2000; Lr48 (Bansal et al. 2008) Zhang et al. 2016)

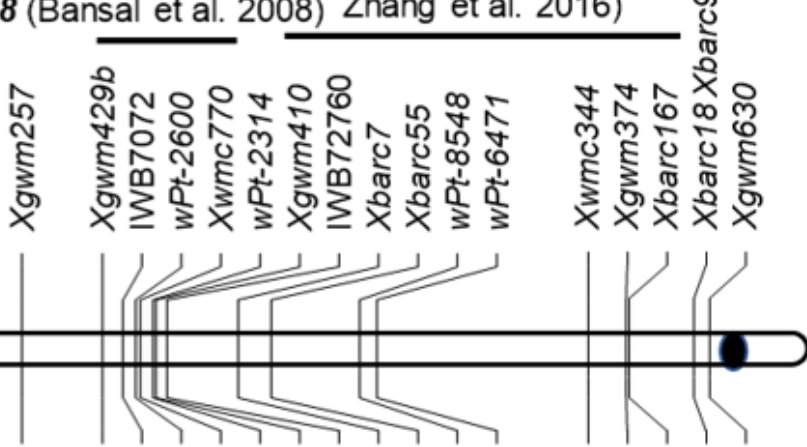

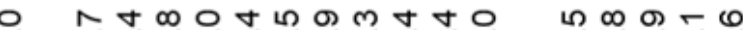

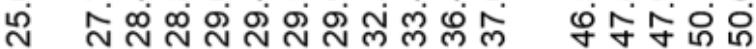

B

Lr23 (Chhetri et al. 2017)

LrCH1539

Lr48 (Bansal et al. 2008)

Lr16 (Kassa et al. 2017)

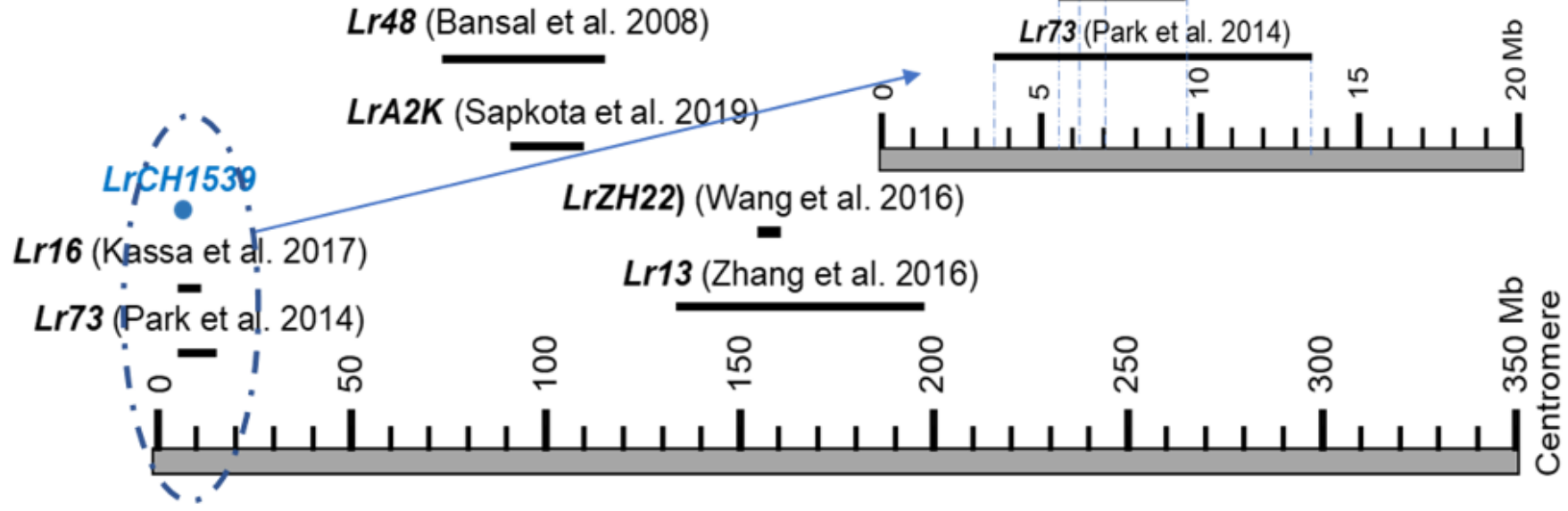

Figure 7

(A) $\mathrm{LrCH} 1539$ identified in the present study and Pt genes previously mapped were positioned based on the integrated genetic map (Maccaferri et al. 2015). RD: Relative distance. The centromere region is displayed in black. The confidence interval of the gene is indicated with black lines. (B) The physical position of LrCH1539 compared with the previously reported $L$ rgenes for seedling resistance to leaf rust on 2BS (10-Mb tick size map). The black bar indicates an interval harboring an Lrgene flanked by two markers, and the dot indicates a single marker representing an $\operatorname{Lrgene}$.

\section{Supplementary Files}

This is a list of supplementary files associated with this preprint. Click to download.

- SupplementryFigure1.png 
- 20220126LrCH15392BSTableS14.xIsx

Page 20/20 